Island Studies Journal, Vol. 11, No. 2, 2016, pp. 431-436

\title{
An island, some fishers, and a few placenames: a research note
}

\author{
Joshua Nash \\ University of New England \\ Australia \\ joshua.nash@une.edu.au
}

\begin{abstract}
The social and linguistic status of Norfolk Island placenames is explored through a creative process based in fieldwork engagement. A personal narrative is proffered relating the human-human interface of investigative interaction with local fishers to their sociocultural environment. One of the means Norfolk Islanders make sense of their remote island is through names and other mediated social and ecological relationships.
\end{abstract}

Keywords: contact language typology, creative writing, fieldwork engagement, insularity, Norfolk Island (South Pacific), toponymy

(C) 2016 - Institute of Island Studies, University of Prince Edward Island, Canada.

\section{Introduction}

For an island with a land area of $35 \mathrm{~km}^{2}$, Norfolk Island has many places and plenty of names (Figure 1). On my first visit, with a map to locate myself on the island's bumpy, sometimes potholed, thoroughfares, I searched out these places and names. Dead end roads, ultimately leading nowhere, restricted by cliffs and shores. The speed limit is $50 \mathrm{~km}$ per hour and cows have right of way. I learned moving around by bicycle would help me see more of the island. The slow speed allowed me to take more in, watch the movements of the trees, the birds, and what I was there to observe: relationships between people, place, language, maps, and names.

I am stationed as a toponymist to document the local history, land use changes, and linguistic import associated with the many little known, localized, and esoteric placenames. The elucidatory nature of Norfolk Island toponymy is its confinement, its insularity, and the contradictions between known-unknown and insider-outsider, relating people to place through language. I interpret an extensive complex of name, place, and people links built up over time made available only to those allowed access to family properties and onshore and offshore fishing places. There is a lot wisdom contained within Norfolk Island placenames. It is this content (what they mean culturally) more than the location and form of the names (their grammatical stature) which attracts my attention.

The knowledgeable fisherman Bev McCoy lived on Rooty Hill Road with his wife Dos. They married in their early twenties in the 1940s. In a scratchy $8 \mathrm{~mm}$ wedding film I acquired, Bev appears as a strong, attractive man with a proud wife by his side. They are both dead now but they are well remembered in the Norfolk Island community's memory. My narrative begins in their house on Rooty Hill Road, named House Road in Norfolk, the Norfolk Island language, in early 2008. House Road leads down to the Georgian houses on Quality Row in Kingston, the only flat, low lying area of any significant size on this tiny archipelago consisting of three islands-Norfolk Island, Nepean Island, and Philip Island. On the way down House Road one passes Queen Elizabeth Lookout which is known locally as 
Lizzie's Lookout or simply Lizzie's. From here, one can see down the rolling hills to the golf course, Government House, Nepean, Phillip, and out to the vast expanses of the South Pacific. Norfolk Island is extremely isolated. I try to imagine the newly-arrived Pitcairn Islanders plying the incessant waves and their lilting language as they sought their livelihood in the sea's bounty.

\section{Figure 1: Map of Norfolk Island.}

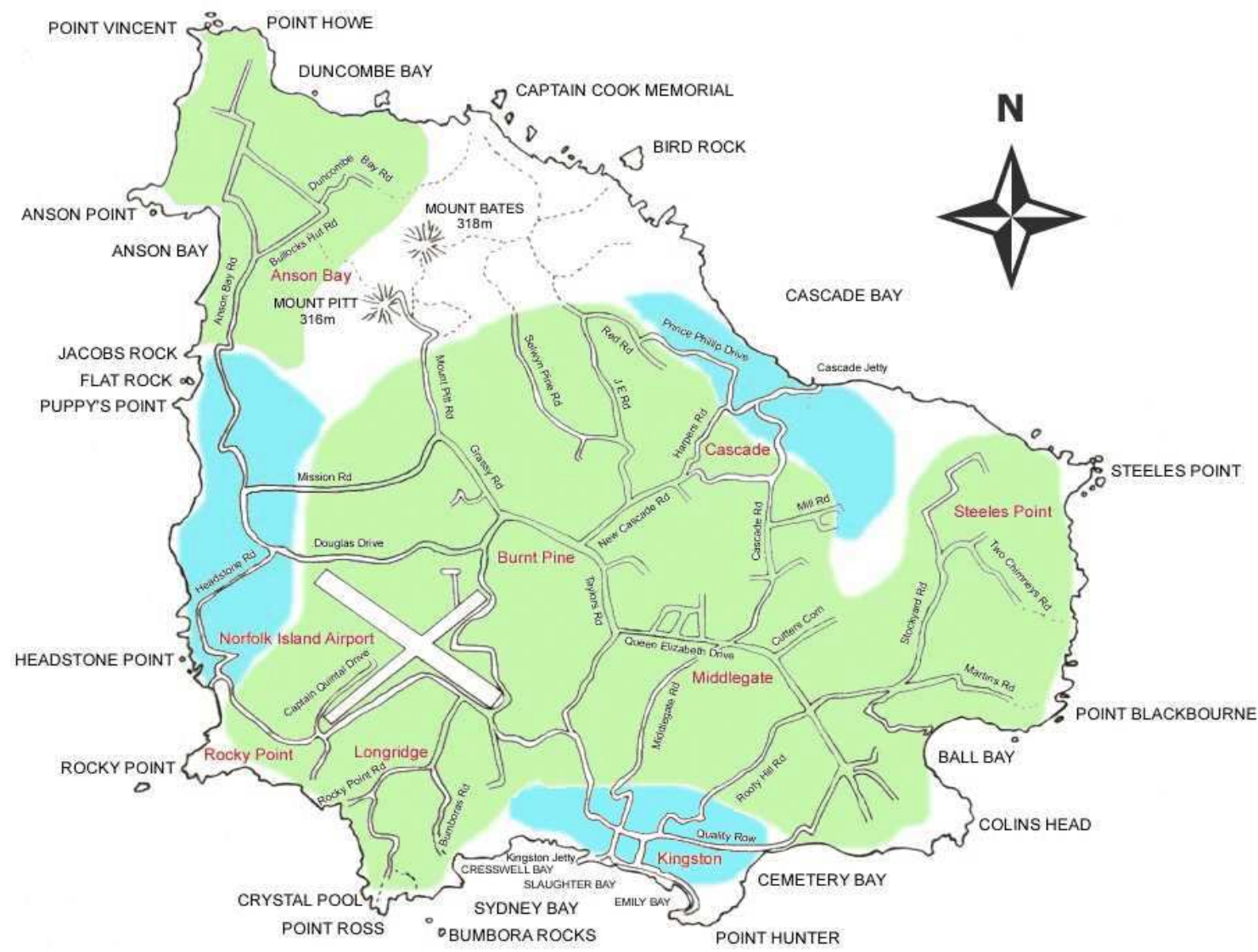

Sources: http://www.mappery.com/maps-Norfolk-Island and http://www.ni.net.nf/images

The Pitcairn Islanders, the descendants of the Bounty mutineers and a group of Polynesian women, arrived on Norfolk Island in 1856. Whether or not one is of Pitcairn Island descent is one of the main stories that creates and divides the Norfolk Island community. Bev's grandparents would have been born on Pitcairn Island more than 5,000 km away. I question whether island places are any different from continental places. This island space is perceivably more remote than its mainland counterpart, yet some of it is more easily known and accessible. Places are strange, abtruse entities, easily shifted, disturbed, roiled. Instead of remaining fixed, they can fluctuate and move around, their essence dependent on situation and need. Their meanings are not intrinsic or essential, rather their value, what they denote, their ontology are associated with actual people, tangible events, and time. Some are more 
accessible than others, more or less insular. Norfolk Island toponyms can be easily pinpointed on available public maps. Others require more sophisticated means to enter. I realize the islandness and acknowledge the island-like nature of this wee society. I am patient.

What is distinct about Norfolk Island's placenames is that they link a spatial orientation system that uses an intricate network of fixed coordinates, similar to North-East-South-West in English. Unlike English, however, these axes and their relationship to the island's geography are delineated by grammatically agreed upon spatial prepositions, descriptors of space - up, out, round, down. Everyone knows you cannot go 'up Steels Point' but must go 'out Steels Point'. You can only go 'up in a stick', up to the forested areas in the north of the island, and nothing else. This fixed method of spatial description, which is more complex than English, is a historical linguistic artefact transferred from Pitcairn Island. Was it the influence of a nautical navigation system or some other influence that came through the Polynesian language side that produced these complex frames of spatial reference? What is definite is that a small contact language did develop on Pitcairn Island and, when the entire 194 strong population moved to Norfolk Island, they continued speaking it. Once settled, the Pitcairn Islanders changed some names, and kept some English names, and named their own places, some with Tahitian influence. Bloody Bridge became Dar Naughty Bridge, Emily Bay stayed Emily Bay, Fata Fata and Parloo Park are new names. It seems that language documentation and the writing of language and culture restricts us in some ways while inspiring us in others. I felt a relationship building, an alliance between the Norfolk Islanders and the fieldworker, between islands and continents, language and environment, essence and symbols, sound and silence. After returning from my first trip in 2007, I wrote in my personal diary,

'Autyenna' [Out yonder] is where a famous Australian writer lives. I stumbled upon this large property one day. It's adjacent to the airport runway on New Farm Road. There were motors, old cars, a World War II shed for soldiers and another structure full of old restored cars, one with a sticker on it saying 'Lubbe' (leave us alone), a wellknown political statement-cum-middle finger to external powers who the Norfolk Islanders believe meddle in the island's affairs. Norfolk Island wouldn't be Norfolk Island without Australia.

There was no sign on the gate of Bev and Dos's house. On a wood-stoked stove, a kettle simmered constantly. There were fishing artefacts all around, symbols of years spent on the sea. From the back window there was a magnificent view to Collins Head and the surrounding sea. I stopped for a minute, noticing. And here I met for the first time Bev McCoy, 84 year old Norfolk Islander. With a map and ruler on the table, he asked me what I wanted to know. I told him I was aware of a few of the fishing grounds, and that I was hoping he could show me how to locate them and other ones. "Gut plenty more," said Bev, in his broad Norfolk Island English, the variety of English influenced largely by Australian English and which is spoken in parallel with Norfolk. Sitting in this living room, I was led into an inner sanctum of Norfolk Island folklore. Islanders had told me that Bev was a tough nut to crack. However, all I experienced in his presence was gentleness, warmth, and invitations to return. I left in February 2008 with a comprehensive map of the offshore fishing grounds, their names and, happily, their histories, too. A legacy written. A man, an islander, remembered in maps and names. 
Bev was only one of the fishermen I interviewed during several field trips. He was, however, the gem of the lot. During these encounters I had elicited offshore fishing ground names in various informal interviews with the Norfolk Island population. I became aware of names such as No Trouble, Horse \& Cart, and Ar Side fer Doddos. No one can remember the history of who Doddos was. I was told these offshore locations were all named and were lined up using an intricate system of triangulation marking, the specifics of which no fisherman would convey to the uninitiated, even less a linguist from the mainland. I did smell an important lead and one which I, and the Norfolk Island community, have now come to appreciate - the importance of documenting these fishing grounds as an offshore cultural map related intrinsically to the Norfolk Islanders' livelihood and fishing culture.

Everyone seems to have a nickname. Byron is known mostly as Truck, his brother Boyd is Hummy, because his father was. Just before Puss was about to get married, his fiancée was asked by a priest what her groom's real name was. She didn't know his birth name. George 'Puss' Anderson is another of the older experienced fishermen, who eventually warmed to my request for an interview. I went to see Puss at his house, a classic Norfolk Island house named 'Barnaby' adjacent the area known in Norfolk as Out Ar Mission, Out at the Melanesian Mission in English. He is an avid proponent for the revival and survival of Norfolk. The area known as Munnas where he used to work in Kingston, or Down-a-Town, is the place where I heard the most Norfolk spoken. Workers meet there during smoko for cups of coffee or tea and finger buns while the waves roll into Kingston Pier. These are the same men that man the ship, The Norfolk Guardian, which arrives every six weeks or so with supplies for the island.

It was at Munnas and around Kingston Pier that I met Speed, Snoopy, Bodh, Tardy, and Bear, the latter two taking me under their wing by showing me what they knew of the island's fishing lore. I was even told through Bodh that Tardy was looking forward to my next visit. The Norfolk Islanders can be understated and seem aloof but once they like you they always welcome you. One evening Truck phoned me. He had seen Bev at the hospital that day during his weekly dialysis session. Truck told Bev, whose nickname was 'Didda', that there was a young man over from Adelaide who was collecting placenames and fishing grounds; he let Bev know that this man was sincere and that he should help him out lest all this locational and cultural information be lost once Bev was gone. "Send him down!" was the response. That was the initiation which led to my first meeting on Rooty Hill Road.

There has been a debate in language contact studies about the typological status of Norfolk. It is not a pidgin, creole, or mixed language. It has a large stock of prepositions, advanced consonant clustering, and a large number of diphthongs, features uncommon to pidgins, creoles, and other contact languages. It does not fit into other schemas describing prototypical creole languages either. Linguist Don Laycock wrote in 1989 that Norfolk is a cant, an insider language that starkly designates people within and without the language group. This argument sits with me much better than speculative claims made by linguists who generally work on secondary data, never having had any first-hand contact with the language. Science versus self, art against truth.

Does it really matter what linguists say about Norfolk? I doubt whether this conjecture will alter its puzzling nature. In my notebook, I write Norfolk placenames in my own idiosyncratic way. I avoided the ongoing debate about the representation of the language in island signage. Norfolk Islanders can ultimately write their language any way they like. For the moment, however, I must write and think about a proper method of writing and speaking about places. 
On my first visit to Bev's we spoke for hours, I ever ready with pen, notebook, and camera getting down as much as possible. My conversations with him made me aware of the importance of documenting the placenames on Nepean Island, a short 800 metres south of Norfolk Island, which had never been done. I was amazed because it is such an important and physically prominent part of the island's history. The same goes for Phillip Island. Bev's direction and inspiration made me look far and wide in archives for the story of place-naming on Phillip. I can still imagine the vamping on the piano and the traditional island food like 'pilhai' (baked grated kumera pie), 'mudda' (green banana dumplings cooked in milk), and coconut bread all drowned in lots of 'Norfolk Island gravy' (cream). There would have definitely been more Norfolk spoken in this house than English.

Out from Cockpit Waterfall are the fishing grounds to the north like Bill's, Shallow Water, and Dar House fer Ma Nobby's. The latter name shows a typical method of naming fishing grounds based on topographical features. It uses the house of Ma Nobby in one of the marks. As generic and as common as it seems, I am yet to find similar fieldwork methods or linguistic analysis of fishing ground names. Aesthetic venture of toponymic data collection aside, I have a job to do and some boxes to tick.

There is a placename common form, Dar Side fer Honey's (literally 'the place of Honey's'). This can be shortened to Honey's without any loss of cultural or historical insight. There appears to be a relationship between the syntactic element 'Dar Side fer...' and the semantic element 'Honey's'. This theoretical position sees the syntactic dialectically related to the semantic, the referatum to the referent and the (linguistically) manifest to the (linguistically) unmanifest as a system. The two 'halves' make sense of one another. This 'making sense' of one another and each part adheres to the general idea held in grammar that the whole is greater than the sum of its parts. That is, the dropping of 'side' (place) still implies that Dar fer Honey's refers to a specific place, the placename specific Honey's. Possessing insider knowledge means that one knows that 'Honeys' is referring to 'Dar Side fer Honey's'. Conversely, a generic as a referatum (place or side) cannot exist without referring to a referent, which has to be more present, although perhaps hidden or more esoteric and culturally encoded than the external, syntactic, or referatum element of a name. What is new and ambitious is my claim that this semantic-syntactic relationship resembles a manifestunmanifest relationship, where the semantic, ethnographic, or meaning element of the placename is brought into the world through a manifestation of its grammaticality in the syntactic. I doubt any creolist or toponymist would take my claim seriously.

Maybe it is in these names and forms that the memories of personalities like Bev McCoy live on. At this stage in my research I am not sure whether there will ever be a clear and accurate classification of Norfolk. Does there need to be? People like Bev still speak it. They use it to remind themselves of who they are, what their ancestry is, and where they find themselves.

Bev had become a permanent resident at the Norfolk Island Hospital when I last saw him. When I walked into the ward the matrons asked in broad Norfolk, 'Who's yu?' Bev just smiled. While his body was obviously deteriorating, his mind was as sharp as ever. I asked him how he was. He was not able to answer. His voice was weak and his breathing static and jolty. I handed him a map and a piece of paper with handwritten information he had compiled some years before. He could hardly hold the paper in his hand. I had documented what Bev told me. I knew this would be the last time I would see him. 


\section{Select Bibliography}

Buffett, A. (1999). Speak Norfolk today: An encyclopedia of the Norfolk language. Norfolk Island: Himii Publishing.

Islands magazine: poetry and creative writing magazine about islands, especially Australian islands.

LINQ. (2010). Literature of Northern Queensland, special issue on islands, 37, December.

Mühlhäusler, P. (2008). Multifunctionality in Pitkern-Norf'k and Tok Pisin. Journal of Pidgin and Creole Languages, 23(1), 75-113.

Nash, J. (2014). Obtuse anglers: fishing ground names and the linguistics and ethnography of fishing on Norfolk Island. In I. D. Clark, L Hercus, L. Kostanski (Eds.), Indigenous and minority place names: Australian and International perspectives (pp. 299-318). Canberra, Australia: Australian National University E-Press.

Nash, J. (2013). Insular toponymies: Place-naming on Norfolk Island, South Pacific and Dudley Peninsula, Kangaroo Island. Philadelphia PA: John Benjamins.

Nobbs-Palmer, B. (1986). A dictionary of Norfolk Words and Usages. Norfolk Island: Photopress International.

Wisemann, B. (1977). Living on Norfolk Island, Norfolk Island: Photopress International. 